\title{
ASCO 2018: highlights of urothelial cancer and prostate cancer
}

\author{
Renate Pichler (D) - Wolfgang Horninger • Isabel Heidegger
}

Received: 25 June 2018 / Accepted: 10 July 2018 / Published online: 24 July 2018

(C) The Author(s) 2018

\begin{abstract}
Summary Prostate cancer and urothelial carcinoma are the two most common urological cancers. The aim of this short review is to highlight abstracts from this year's ASCO Annual Meeting. The phase III SPCG13 trial showed no difference in biochemical diseasefree survival by the addition of docetaxel after primary radiation therapy of localized high-risk prostate cancer. In bone dominant metastatic castration resistant prostate cancer, the phase II radium-223 dose escalation study concluded that the currently used dose with 6 cycles of $55 \mathrm{kBq} / \mathrm{kg}$ remains the standard of care. The PARP inhibitor olaparib plus abiraterone provided a significant benefit in radiological progression-free survival compared with abiraterone alone, independent of homologous recombination repair (HRR) mutation status. In localized muscle-invasive urothelial carcinoma, two phase II trials (ABACUS and PURE-01) exploring the pathological complete remission rate of atezolizumab and pembrolizumab prior to cystectomy in cisplatin-unfit or cisplatin-fit patients are presented. Novel targeted therapies such as fibroblast growth factor receptor (FGFR) inhibitors or monoclonal antibodies against nectin- 4 confirmed astonishing objective response rates in heavily pretreated metastatic urothelial carcinoma (mUC) patients, resulting in a median overall survival (OS) up to 13.8 months. Finally, updated 1-year and 2-year OS survival rates of pembrolizumab and atezolizumab in the first line setting of mUC are presented.
\end{abstract}

\footnotetext{
Assoc. Prof. R. Pichler, MD, PhD, FEBU $(\bowtie) \cdot$ W. Horninger .

Assoc. Prof. I. Heidegger, MD, PhD, FEBU ( $\triangle)$

Department of Urology, Medical University Innsbruck,

Anichstreet 35, 6020 Innsbruck, Austria

Renate.Pichler@i-med.ac.at;

Isabel-Maria.Heidegger@i-med.ac.at
}

Keywords Prostate cancer · Bladder cancer · Urothelial carcinoma - PARP inhibitors - Immunotherapy • Neoadjuvant chemotherapy

Prostate cancer and urothelial cancer are the two leading urological tumor entities [1, 2]. Consequently, multiple clinical studies are ongoing either to cure patients with localized disease or to delay tumor progression in advanced stages of the disease.

Even at the latest ASCO 2018 meeting a large number of clinical studies were reported, with clinical practice changing studies in the near future especially in bladder cancer.

\section{Localized prostate cancer}

\section{Adjuvant docetaxel after primary radiation therapy}

The authors of the SPCG-13 trial presented data from a phase III randomized study analyzing the impact of adjuvant docetaxel therapy after primary radiation $(\geq 74 \mathrm{~Gy}$ ) in patients with localized prostate cancer. All patients were required to harbor an intermediate (PSA $10-20 \mathrm{ng} / \mathrm{ml}$ or biopsy Gleason score 7 or cT2b-cT2c) or high risk (PSA $>20 \mathrm{ng} / \mathrm{ml}$ or biopsy Gleason score $8-10$ or $\geq \mathrm{cT3a}$ ) stage of the disease. In addition to the routinely used androgen deprivation therapy, all patients were randomized either to 6 cycles docetaxel $\left(75 \mathrm{mg} / \mathrm{m}^{2}\right)$ or to placebo after radiation. The primary endpoint of the study was biochemical recurrence defined as a rising $P S A \geq 2 \mathrm{ng} / \mathrm{ml}$ above the nadir PSA value.

Although promising former studies on this issue, statistical analyses including 378 patients revealed no significant difference in biochemical disease-free survival in both arms at 5-year follow-up (progression: +docetaxel vs. surveillance: $31 \%$ vs. $30.3 \%, p=0.631$ ), 
[3]. To summarize, the present study showed that adjuvant docetaxel treatment does not improve biochemical disease-free survival after radiotherapy in intermediate- or high-risk prostate cancer. However, final results of the RTOG0521 study [4] as well as the subanalysis of the STAMPEDE trial [5] also investigating this topic have to be awaited before drawing any final conclusion of the impact of adjuvant docetaxel therapy in patients with intermediate- or highrisk prostate cancer.

\section{Metastatic castration resistant prostate cancer (mCRPC)}

Androgen deprivation therapy is an important backbone treatment in advanced/metastatic prostate cancer; however, most patients will develop a castrationresistant status after 2-3 years. According to the current EAU guidelines castration resistant prostate cancer (CRPC) is defined as serum testosterone $<50 \mathrm{ng} / \mathrm{dL}$ or $1.7 \mathrm{nmol} / \mathrm{L}$ plus (1) biochemical progression (3 consecutive PSA rises one week apart resulting in two $50 \%$ increases over the nadir, and a PSA $>2 \mathrm{ng} / \mathrm{mL}$ ) or (2) radiological progression (new lesions either 2 or more new bone lesions on bone scan or a soft tissue lesion) [6]. In recent years, several new treatment options have been approved for this stage of the disease (Fig. 1); however, recent data from a hospitalbased registry revealed that these new agents since 2010 showed a modest benefit on overall survival rates in metastatic CRPC patients, with a median improvement of 6 months [7].

Therefore, there is need of improvement of existing therapies, development of new therapeutic agents as well as gain of a better knowledge about combining approved and upcoming therapeutic agents.

\section{Radium-223 dosis escalation}

According to the pivotal study published several years ago radium-223 is administered for 6 cycles with a dose of $55 \mathrm{kBq} / \mathrm{kg}$ in patients with bone dominant metastatic CRPC [8].
At the recent ASCO meeting, Sternberg et al. presented data of a phase II study comparing the standard radium-223 dose versus a high dose $(88 \mathrm{kBq} / \mathrm{kg}$ for 6 cycles) as well as versus an increase of treatment cycles from 6 to $12(55 \mathrm{kBq} / \mathrm{kg}$ for 12 cycles $)$. Primary endpoint of the study was the symptomatic skeletal event-free survival. Data clearly showed after enrollment of 381 patients no difference in symptomatic skeletal event-free survival among the treatment groups. However, in both treatment arms with extended radium-223 treatment higher incidences of grade 3 treatment-related adverse events were observed [9].

Therefore, the authors concluded that the currently used doses of $55 \mathrm{kBq} / \mathrm{kg}$ up to 6 cycles remain standard of care in patients with symptomatic bone dominant metastatic CRPC without any $>3 \mathrm{~cm}$ lymph node or visceral metastases [9].

\section{Radium-223 plus enzalutamide}

Both radium-223 [10] and the androgen receptor inhibitor enzalutamide $[11,12]$ are therapeutic options in patients with bone dominant metastatic CRPC.

Maughan et al. presented safety data from a phase II randomized trial of 49 patients treated with the combination of radium-223 plus enzalutamide versus enzalutamide alone. Interestingly they observed no difference in serious adverse events regardless of attribution between two arms [13].

This finding is in contrast to a phase III study (ERA 223, NCT02043678) combining radium-223 plus the CYP17 inhibitor abiraterone. Several months ago, the EMA stopped this trial because $34.7 \%$ of patients treated with radium-223/abiraterone had died so far, compared with $28.2 \%$ of patients given abiraterone monotherapy. Fractures were also occurred more frequently with the radium-223 combination than the placebo combination ( $26 \%$ vs. $8.1 \%)$. Until now the reasons for the increased number of deaths in the combination arm remains speculative.
Fig. 1 Overview of approved agents in metastatic castration resistant prostate cancer (blue arrows) including their year of approval. Future new treatment options are highlighted in black, treatment options discussed in this manuscript are marked in red with *. PARP poly ADP ribose polymerase, PSMA prostate-specific membrane antigen

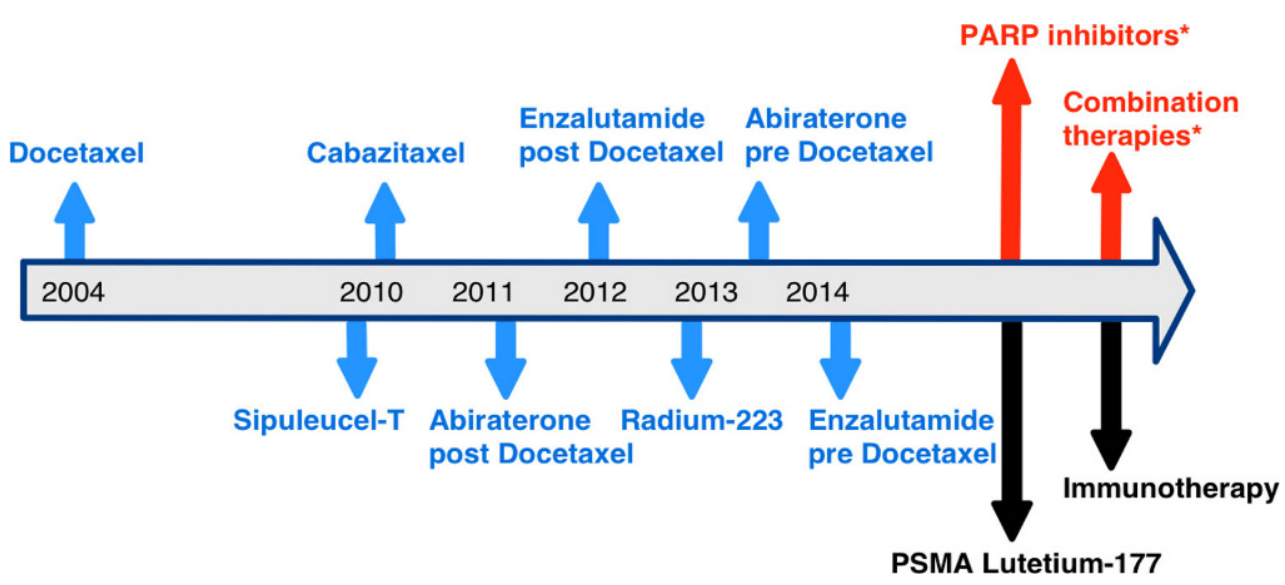

PSMA Lutetium-177 
Table 1 Results of the phase II ABACUS and PURE-01 trial testing atezolizumab and pembrolizumab in the neoadjuvant setting prior to radical cystectomy

\begin{tabular}{|c|c|c|c|}
\hline & & $\begin{array}{l}\text { ABACUS } \\
\text { [23], Abstract \#4506 }\end{array}$ & $\begin{array}{l}\text { PURE-01 } \\
\text { [24], Abstract \#4507 }\end{array}$ \\
\hline \multicolumn{2}{|c|}{ Phase } & $\|$ & ॥ \\
\hline \multicolumn{2}{|c|}{ Study population (n) } & 68 & 43 \\
\hline \multicolumn{2}{|c|}{ Checkpoint inhibitor } & Atezolizumab & Pembrolizumab \\
\hline \multicolumn{2}{|c|}{ Number of cycles } & 2 & 3 \\
\hline \multicolumn{2}{|c|}{ Cisplatin-fit? } & Cisplatin-unfit & Cisplatin-fit \\
\hline \multicolumn{2}{|c|}{ Residual tumor after TURB } & Yes & Yes \\
\hline \multicolumn{2}{|c|}{ TNM for inclusion } & CT2-T4aN0-N1 & $\leq \mathrm{cT} 3 \mathrm{bNO}$ \\
\hline \multirow[t]{5}{*}{ pCR } & Overall & $29 \%$ & $39.5 \%$ \\
\hline & PD-L1+ & $40 \%(\geq 5 \%$ IC) & $50 \%$ (CPS score $\geq 20 \%$ ) \\
\hline & \multirow[t]{3}{*}{ PD-L1- } & \multirow[t]{3}{*}{$16 \%$} & - \\
\hline & & & PD-L1+ and DDR/RB1-GA: 90\% \\
\hline & & & DDR and/or RB1-GA: $60 \%$ \\
\hline \multicolumn{2}{|c|}{ Discontinuation/progression during CPI ( $n$ ) } & $1(1.5 \%)$ & $1(2.3 \%)$ \\
\hline \multicolumn{2}{|c|}{ Most common AEs } & $21 \%$ fatigue & $11 \%$ hyperthyroidism \\
\hline \multirow{3}{*}{\multicolumn{2}{|c|}{ Biomarkers }} & PD-L1 & CPS Score, TMB \\
\hline & & \multirow[t]{2}{*}{ CD8 } & 22-gene T-cell inflamed panel qPCR \\
\hline & & & Genomic profiling \\
\hline
\end{tabular}

Table 2 Overview of updated survival data of the KEYNOTE-052 and IMvigor 210 (cohort 1) trial in comparison to results of the EORTC 30986

\begin{tabular}{|l|l|l|l|} 
& KEYNOTE-052 & IMvigor210 (Cohort 1) & EORTC 30986 \\
& {$[29]$, Abstract \#4524 } & [28], Abstract \#4523 & [25], Gemcitabine/carboplatin \\
\hline Study population $(n)$ & 370 & 119 & 238 \\
\hline ORR (\%) & 28.9 & 24 & 36 \\
\hline CR Rate (\%) & 8.1 & 8 & 6.1 \\
\hline Median OS (months) & 11.5 & 16.3 & 9.3 \\
\hline 1-Year OS rate (\%) & 47.5 & 58 & 37 \\
\hline 2-Year OS rate (\%) & - & 41 & 18 \\
\hline ORR objective response rate, OS overall survival, $C R$ complete response & \\
\hline
\end{tabular}

\section{PARP inhibition}

In 2017 Mateo et al. reported in a phase II study that the PARP inhibitor olaparib significantly increased overall survival in patients no longer responding to standard treatments who had defects in DNA repair genes [14]. To further increase the efficacy a phase II study combining olaparib with abiraterone has been conducted whose mechanistic rationale is a previous preclinical study that PARP is involved in androgen receptor transcription [15].

At the ASCO meeting Clarke et al. reported data of 140 patients randomized either to olaparib monotherapy or to the combination olaparib/abiraterone. The primary endpoint of the study was the radiologic progression-free survival (rPFS). Fortunately, the combined treatment prolonged rPFS from 8.2 to 13.2 months $(p=0.034)$ with a HR of 0.65 . Interestingly a subgroup analysis showed that patients without homologous recombination repair mutations also benefited from therapy. Despite highly promising response data, one must be concerned that in the combination arm significantly higher numbers of grade 3 treatment-related adverse events mainly focusing on cardiac events were observed [16].

\section{Localized muscle-invasive bladder cancer (MIBC)}

\section{Checkpoint inhibitors in the neoadjuvant setting prior to radical cystectomy}

Cisplatin-based neoadjuvant chemotherapy followed by radical cystectomy is currently the gold standard in localized MIBC according to the EAU guidelines [17]. Cisplatin-based neoadjuvant chemotherapy achieves pathological complete response (pCR) rates in about $30 \%$ [18], resulting in a median 5-year overall survival (OS) benefit of $5-8 \%$ and a $16 \%$ reduction in mortality risk [19, 20]. Nevertheless, chemotherapy-associated toxicities, delayed cystectomy, no available biomark- 
Table 3 Results of novel targeted therapies using FGFR inhibitors (rogaratinib, erdafitinib) and nectin-4 monoclonal antibody (enfortumab) in heavily pretreated mUC patients

\begin{tabular}{|c|c|c|c|}
\hline & $\begin{array}{l}\text { ROGARATINIB } \\
\text { [37], Abstract \#4513 } \\
N=51\end{array}$ & $\begin{array}{l}\text { ERDAFITINIB } \\
\text { [38], Abstract \#4503 } \\
N=99\end{array}$ & $\begin{array}{l}\text { ENFORTUMAB } \\
\text { [42], Abstract \#4504 } \\
N=112\end{array}$ \\
\hline Phase & 1 & ॥ & 1 \\
\hline Dosage & $800 \mathrm{mg}$ twice daily & $8 \mathrm{mg}$ daily (up to $9 \mathrm{mg}$ ) & $1.25 \mathrm{mg} / \mathrm{kg}$ (day $1,8,15$ ) \\
\hline Target & FGFR1-4 & FGFR1-4 & Nectin-4 \\
\hline \multirow[t]{3}{*}{ Inclusion criteria } & $\geqq 1$ line Cx & $\geqq 1$ line $\mathrm{Cx}$ or & $\geqq 1$ line Cx or \\
\hline & Cisplatin-unfit & Cisplatin-unfit & \\
\hline & Prior I0 allowed & Prior 10 allowed & Prior I0 allowed \\
\hline Visceral metastasis & \multirow[t]{4}{*}{-} & $79 \%$ & $77 \%$ \\
\hline Crea Clearance $<60$ & & $53 \%$ & $50 \%$ \\
\hline$\geqq 2$ lines systemic $\mathrm{Cx}$ & & $43 \%$ & $63 \%$ \\
\hline Prior 10 & & $23 \%$ & $79 \%$ \\
\hline \multirow[t]{3}{*}{ FGFR mutations } & FGFR3+ $87 \%$ & FGFR3 mutation $75 \%$ & \multirow[t]{3}{*}{-} \\
\hline & FGFR $1+5 \%$ & \multirow[t]{2}{*}{ FGFR2/3 fusion 25\% } & \\
\hline & Dual FGFR +8\% & & \\
\hline \multicolumn{4}{|l|}{ ORR } \\
\hline Overall & $24 \%$ & $40.4 \%$ & $41 \%$ \\
\hline Prior 10 & $30 \%$ & $59 \%$ & $40 \%$ \\
\hline Visceral metastasis & - & $38.5 \%$ & $39 \%$ \\
\hline Median PFS (months) & - & 5.5 & 5.4 \\
\hline Median OS (months) & - & 13.8 & 13.6 \\
\hline \multirow[t]{3}{*}{ AEs } & Diarrhea (60.8\%) & Hyperphosphatemia (73\%) & Fatigue (54\%) \\
\hline & Hyperphosphatemia (45.1\%) & Skin disorders (49\%) & $\begin{array}{l}\text { Grade } \geqq 3 \text { AEs: anemia } 8 \% \text {, hyponatremia } \\
7 \% \text {, UTI } 7 \% \text {, and hyperglycemia } 6 \%\end{array}$ \\
\hline & Nail disorders (52\%) & & \\
\hline
\end{tabular}

ers and the fact that more than $50 \%$ of patients are not eligible for cisplatin are reasons for low referral and treatment rates of neoadjuvant chemotherapy [21], although neoadjuvant chemotherapy is not associated with higher perioperative morbidity or mortality [22]. At the ASCO meeting, preliminary results of two phase II trials using atezolizumab [23] (ABACUS) and pembrolizumab [24] (PURE-01) in the neoadjuvant setting were presented. A comparison of these two trials is shown in Table 1. In summary, overall pCR rates were comparable to neoadjuvant chemotherapy, which enriched to $50 \%$ in PD-L1 positive patients, and to $90 \%$ in PD-L1 positive patients with additional DNA damage repair (DDR) or retinoblastoma (RB1) genomic alteration. Sequential biomarker analysis showed a dynamic increase in PD-L1 und CD8 expression with atezolizumab. Using pembrolizumab, $\mathrm{T}$ cell-inflamed signatures significantly discriminated pT0 from non-pT0 patients. In summary, neoadjuvant immunotherapy was associated with few side effects, no delayed surgery with similar pCR rates to chemotherapy, being a novel hopeful approach especially in cisplatin-unfit patients.

\section{Metastatic urothelial carcinoma (mUC)}

Overall survival (OS) updates of pembrolizumab and atezolizumab in the 1st line setting of cisplatin-unfit patients

Compared to the results of the EORTC 30986 trial by De Santis M et al. [25] that examined two carboplatin-based chemotherapy regimens (gemcitabine/ carboplatin and methotrexate/carboplatin/vinblastine) in cisplatin-unfit patients [25], the survival update analysis of the KEYNOTE-052 [26] and IMvigor210 (cohort 1, [27]) studies presented at this ASCO meeting by Balar et al. [28] (Abstract \#4523) and Vuky et al. [29] (Abstract \#4524) confirmed a better median OS, 1-year and 2-year OS rate as shown in Table 2.

Nevertheless, according to preliminary data from the ongoing KEYNOTE-361 (NCT02853305) and IMvigor130 trial (NCT02807636) showing reduced survival with pembrolizumab and atezolizumab compared with standard chemotherapy in mUC patients who have not received prior therapy and whose tumors have low PD-L1 expression, the European Medicines Agency (EMA) restricts pembrolizumab and atezolizumab as monotherapy in the first-line setting only for cisplatin-unfit patients with high PD- 
L1 expression ( $\geq 5 \%$ for atezolizumab; tumoral CPS score $\geq 10 \%$ for pembrolizumab) $[30,31]$.

\section{Targeted therapies in chemotherapy- and IO-refractory mUC}

Previous trials have shown that responses to chemotherapy and IO vary by The Cancer Genome Atlas (TCGA) molecular subtyping in MIBC [32-34]. The luminal papillary I subtype UC is characterized by FGFR3 alterations [35], confirming no benefit from neoadjuvant chemotherapy prior to cystectomy [34] and being immunologically "cold" with no clear response to checkpoint inhibitors [32, 36]. Thus, patients with luminal I subtype may be ideal candidates for FGFR inhibitors. Results of phase I and II trials evaluating two FGFR inhibitors, rogaratinib [37] (Joerger $\mathrm{M}$ et al., Abstract \#4513) and erdafitinib [38] (Siefker-Radtke A et al., Abstract \#4503), in heavily pretreated mUC patients with FGFR alterations confirmed astonishing objective response rates in up to $40.4 \%$, increasing to $59 \%$ in those patients with prior IO. The median OS (13.8 months) for erdafitinib was higher compared to pembrolizumab (KEYNOTE-045: 10.1 months; [39] Fradet $\mathrm{T}$ et al., Abstract \#4521) and atezolizumab (Imvigor211: 11.1 months [40]; IMvigor210 cohort 2: 7.9 months, [28] Balar et al., Abstract \#4523) in the second line setting. Thus, a phase III trial (THOR, NCT03390504) is ongoing randomizing patients for erdafitinib or pembrolizumab or chemotherapy (vinflunine, docetaxel).

Enfortumab, an antibody-drug conjugate that delivers cytostatic drugs to cells expressing nectin-4, a transmembrane cell adhesion molecule which is expressed in $83 \%$ of UC [41], showed similar results in a phase I trial (Rosenberg JE et al. [42], Abstract \#4504) as erdafitinib concerning ORR and median OS (Table 3). Due to this encouraging preliminary findings, enfortumab will be evaluated in the third line setting compared to chemotherapy (vinflunine, docetaxel, paclitaxel) in a phase III trial in patients who progressed after platinum-based chemotherapy and IO therapy (NCT03474107).

Funding Open access funding provided by University of Innsbruck and Medical University of Innsbruck.

Conflict of interest R. Pichler, W. Horninger and I. Heidegger declare that they have no competing interests.

Open Access This article is distributed under the terms of the Creative Commons Attribution 4.0 International License (http://creativecommons.org/licenses/by/4.0/), which permits unrestricted use, distribution, and reproduction in any medium, provided you give appropriate credit to the original author(s) and the source, provide a link to the Creative Commons license, and indicate if changes were made.

\section{References}

1. Siegel RL, Miller KD, Jemal A. Cancer statistics, 2016. Ca Cancer JClin. 2016;66(1):7-30.

2. Antoni S, Ferlay J, Soerjomataram I, Znaor A, Jemal A, Bray F. Bladder cancer incidence and mortality: a global overview and recent trends. Eur Urol. 2017;71(1):96-108. https://doi. org/10.1016/j.eururo.2016.06.010.

3. Kellokumpu-Lehtinen P-LI,Hjälm-Eriksson M,AstromL, et al. A randomized phase III trial between adjuvant docetaxel and surveillance after radical radiotherapy for intermediate and high risk prostate cancer: Results of SPCG-13 trial. JClin Oncol. 2018;36(suppl):abstr 5000.

4. Sandler HM, Hu C, Rosenthal SA, et al. A phase III protocol of androgen suppression (AS) and 3DCRT/IMRT versus AS and 3DCRT/IMRT followed by chemotherapy (CT) with docetaxel and prednisone for localized, high-risk prostate cancer (RTOG 0521). J Clin Oncol. 2015;33(suppl):abstr LBA5002.

5. James ND, Sycles MR, Mason MD, et al. Docetaxel and/or zoledronic acid for hormone-naïve prostate cancer: first overall survival results from STAMPEDE (NCT00268476). JClin Oncol. 2015;33(suppl):abstr 5001.

6. Heidenreich A, Bastian PJ, Bellmunt J, Bolla M, Joniau S, van der Kwast T, Mason M, Matveev V, Wiegel T, Zattoni F, Mottet N, European Association of Urology. EAU guidelines on prostate cancer. Part II: treatment of advanced, relapsing, and castration-resistant prostate cancer. Eur Urol. 2014;65(2):467-79. https://doi.org/10.1016/j.eururo. 2013.11.002.

7. Francini E, Gray KP, Shaw G, et al. Impact of new systemic therapies on overall survival (OS) of patients (pts) with metastatic castration resistant prostate cancer (mCRPC) in a hospital-based registry. J Clin Oncol. 2018;36(6 Suppl):203-203. https://doi.org/10.1200/JCO.2018.36:6_ suppl.203.

8. Parker C, Nilsson S, Heinrich D, Helle SI, O'Sullivan JM, Fossa SD, et al. Alpha emitter radium-223 and survival in metastatic prostate cancer. $\mathrm{N}$ Engl J Med. 2013;369(3):213-23.

9. Sternberg CN, Saad F, Graff JN, et al. A randomized phase 2 study investigating 3 dosing regimens of radium-223 dichloride (Ra-223) in bone metastatic castration-resistant prostate cancer (mCRPC). J Clin Oncol. 2018;36(suppl):abstr 5008.

10. Parker C, Nilsson S, Heinrich D, Helle SI, O'Sullivan JM, Fosså SD, ChodackiA, Wiechno P, Logue J, Seke M, Widmark A, Johannessen DC, Hoskin P, Bottomley D, James ND, Solberg A, Syndikus I, Kliment J, Wedel S, Boehmer S, Dall'Oglio M, FranzénL, ColemanR, VogelzangNJ, O'BryanTear CG, Staudacher K, Garcia-Vargas J, Shan M, Bruland ØS, Sartor O, ALSYMPCA Investigators. Alpha emitter radium-223 and survival in metastatic prostate cancer. N Engl J Med. 2013;369(3):213-23. https://doi.org/10. 1056/NEJMoa1213755.

11. Beer TM, Armstrong AJ, Rathkopf DE, Loriot Y, Sternberg CN, Higano CS, Iversen P, Bhattacharya S, Carles J, Chowdhury S, Davis ID, de Bono JS, Evans CP, Fizazi K, Joshua AM, Kim CS, Kimura G, Mainwaring P, Mansbach H, Miller K, Noonberg SB, Perabo F, Phung D, Saad F, Scher HI, Taplin ME, Venner PM, Tombal B, PREVAIL Investigators. Enzalutamide in metastatic prostate cancer before chemotherapy. NEnglJMed. 2014;371(5):424-33. https://doi.org/10.1056/ NEJMoal405095.

12. Scher HI, Fizazi K, Saad F, Taplin ME, Sternberg CN, Miller K, de Wit R, Mulders P, Chi KN, Shore ND, Armstrong AJ, Flaig TW, Fléchon A, Mainwaring P, Fleming M, 
Hainsworth JD, Hirmand M, Selby B, Seely L, de Bono JS, AFFIRM Investigators. Increased survival with enzalutamide in prostate cancer after chemotherapy. N Engl J Med. 2012;367(13):1187-97.

13. Maughan BL, Hoffman JM, Morton K, et al. Safety data from a phase II randomized trial of radium-223 dichloride (Ra223) plus enzalutamide (Enza) vs. Enza alone in men with metastatic castration refractory prostate cancer (mCRPC). JClin Oncol. 2018;36(suppl):abstr 5057.

14. Mateo J, Carreira S, Sandhu S, Miranda S, Mossop H, PerezLopezR, etal. DNA-repair defectsand olaparibinmetastatic prostate cancer. NEngl J Med. 2015;373(18):1697-708.

15. Schiewer MJ, Goodwin JF, Han S, Brenner JC, Augello MA, Dean JL, et al. Dual roles of PARP-1 promote cancer growth and progression. Cancer Discov. 2012;2(12):1134-49.

16. Clarke N, Wiechno PJ, Alekseev B, et al. Olaparib combined with abiraterone in patients (pts) with metastatic castration-resistant prostate cancer (mCRPC): a randomized phase II trial. J Clin Oncol. 2018;36(suppl):abstr 5003.

17. AlfredWitjes J, LebretT, CompératEM, Cowan NC, DeSantis M, Bruins HM, Hernández V, Espinós EL, Dunn J, Rouanne M, Neuzillet Y, Veskimäe E, van der Heijden AG, Gakis G, Ribal MJ. Updated 2016 EAU guidelines on muscle-invasive and metastatic bladder cancer. Eur Urol. 2016; https:// doi. org/10.1016/j.eururo.2016.06.020.

18. Petrelli F, Coinu A, Cabiddu M, Ghilardi M, Vavassori I, Barni S. Correlation of pathologic complete response with survival after neoadjuvantchemotherapy in bladder cancer treated with cystectomy: a meta-analysis. Eur Urol. 2014;65(2):350-7. https://doi.org/10.1016/j.eururo.2013. 06.049 .

19. Yin M, Joshi M, Meijer RP, Glantz M, Holder S, Harvey HA, Kaag M, Fransen van de Putte EE, Horenblas S, Drabick JJ. Neoadjuvant chemotherapy for muscle-invasive bladder cancer: a systematic review and two-step meta-analysis. Oncologist. 2016;21(6):708-15. https://doi.org/10.1634/ theoncologist.2015-0440.

20. International Collaboration of Trialists, Medical Research Council Advanced Bladder Cancer Working Party (now the National Cancer Research Institute Bladder Cancer Clinical Studies Group), European Organisation for Research and Treatment of CancerGenito-Urinary Tract Cancer Group, Australian Bladder Cancer Study Group, National Cancer Institute of Canada Clinical Trials Group, Finnbladder, Norwegian Bladder Cancer Study Group, Club Urologico Espanol de Tratamiento Oncologico Group, Griffiths G, Hall R, Sylvester R, Raghavan D, Parmar MK. International phase III trial assessing neoadjuvant cisplatin, methotrexate, and vinblastine chemotherapy for muscle-invasive bladder cancer: long-term results of the BA06 30894 trial. J Clin Oncol. 2011;29(16):2171-7. https://doi.org/10.1200/JCO. 2010.32.3139.

21. Miles BJ, Fairey AS, Eliasziw M, Estey EP, Venner P, Finch D, Trpkov K, Eigl BJ. Referral and treatment rates of neoadjuvant chemotherapy in muscle-invasive bladder cancer before and after publication of a clinical practice guideline. Can Urol Assoc J. 2010;4(4):263-7.

22. Gandaglia G, Popa I, Abdollah F, Schiffmann J, Shariat SF, Briganti A, Montorsi F, Trinh QD, Karakiewicz PI, Sun M. The effect of neoadjuvant chemotherapy on perioperative outcomes in patients who have bladder cancer treated with radical cystectomy: a population-based study. Eur Urol. 2014;66(3):561-8. https://doi.org/10.1016/j.eururo.2014. 01.014.

23. Powles T, Rodriguez-Vida A, Duran I, et al. A phase II study investigating the safety and efficacy of neoadjuvant atezolizumab in muscle invasive bladder cancer (ABACUS). JClin Oncol. 2018;36(suppl):abstr 4506.

24. Necchi A, Briganti A, Bianchi M, et al. Preoperative pembrolizumab (pembro) before radical cystectomy (RC) for muscle-invasive urothelial bladder carcinoma (MIUC): Interim clinical and biomarker findings from the phase 2 PURE-01 study. JClin Oncol. 2018;36(suppl):abstr 4507.

25. De Santis M, Bellmunt J, Mead G, Kerst JM, Leahy M, Maroto P, Gil T, Marreaud S, Daugaard G, Skoneczna I, Collette S, Lorent J, de Wit R, Sylvester R. Randomized phase II/III trialassessinggemcitabine/carboplatinandmethotrexate/ carboplatin/vinblastine in patients with advanced urothelial cancer who are unfit for cisplatin-based chemotherapy: EORTC study 30986. J Clin Oncol. 2012;30(2):191-9. https://doi.org/10.1200/JCO.2011.37.3571.

26. Balar AV, Castellano D, O'Donnell PH, Grivas P, Vuky J, Powles T, Plimack ER, Hahn NM, de Wit R, Pang L, Savage MJ, Perini RF, Keefe SM, Bajorin D, Bellmunt J. First-line pembrolizumab in cisplatin-ineligible patients with locally advanced and unresectable or metastatic urothelial cancer (KEYNOTE-052): a multicentre, single-arm, phase 2 study. Lancet Oncol. 2017;18(11):1483-92. https://doi.org/10. 1016/S1470-2045(17)30616-2.

27. Balar AV, Galsky MD, Rosenberg JE, Powles T, Petrylak DP, Bellmunt J, Loriot Y, Necchi A, Hoffman-Censits J, PerezGracia JL, Dawson NA, van der Heijden MS, Dreicer R, Srinivas S, Retz MM, Joseph RW, Drakaki A, Vaishampayan UN, Sridhar SS, Quinn DI, Durán I, Shaffer DR, Eigl BJ, Grivas PD, Yu EY, Li S, Kadel EE 3rd, Boyd Z, Bourgon R, Hegde PS, Mariathasan S, Thåström A, Abidoye OO, Fine GD, Bajorin DF, IMvigor210 Study Group. Atezolizumab as first-line treatment in cisplatin-ineligible patients with locally advanced and metastatic urothelial carcinoma: a single-arm, multicentre, phase 2 trial. Lancet. 2017;389(10064):67-76. https://doi.org/10.1016/S0140-6736(16)32455-2.

28. Balar AV, Dreicer R, Loriot Y, et al. Atezolizumab (atezo) in first-line cisplatin-ineligible or platinum-treated locally advanced or metastatic urothelial cancer (mUC): Longterm efficacy from phase 2 study IMvigor210. J Clin Oncol. 2018;36(suppl):abstr 4523.

29. Vuky J, Balar AV, Castellano DE, et al. Updated efficacy and safety of KEYNOTE-052: A single-arm phase 2 study investigating first-line pembrolizumab (pembro) in cisplatinineligible advanced urothelial cancer (UC). J Clin Oncol. 2018;36(suppl):abstr 4524.

30. Gourd E. EMA restricts use of anti-PD-1 drugs for bladder cancer. Lancet Oncol. 2018; https://doi.org/10.1016/ S1470-2045(18)30433-9.

31. http://www.ema.europa.eu/ema/index.jsp?curl=pages/ news_and_events/news/2018/05/news_detail_002964. jsp\&mid=WC0b01ac058004d5cl. Accessed: 01.June 2018

32. Sharma P, Retz M, Siefker-Radtke A, Baron A, Necchi A, Bedke J, Plimack ER, Vaena D, Grimm MO, Bracarda S, Arranz JÁ, Pal S, Ohyama C, Saci A, Qu X, Lambert A, Krishnan S, Azrilevich A, Galsky MD. Nivolumab in metastatic urothelial carcinoma after platinum therapy (CheckMate 275): a multicentre, single-arm, phase 2 trial. Lancet Oncol. 2017;18(3):312-22. https://doi.org/10.1016/S14702045(17)30065-7.

33. Rosenberg JE, Hoffman-Censits J, Powles T, van der Heijden MS, Balar AV, Necchi A, Dawson N, O’Donnell PH, Balmanoukian A, Loriot Y, Srinivas S, Retz MM, Grivas P, Joseph RW, Galsky MD, Fleming MT, Petrylak DP, Perez-Gracia JL, Burris HA, Castellano D, Canil C, Bellmunt J, Bajorin D, Nickles D, Bourgon R, Frampton GM, Cui N, Mariathasan S, Abidoye O, Fine GD, Dreicer R. Atezolizumab in patients with locally advanced and metastatic urothelial carcinoma 
who have progressed following treatment with platinumbased chemotherapy: a single-arm, multicentre, phase 2 trial. Lancet. 2016;387(10031):1909-20.https://doi.org/10. 1016/S0140-6736(16)00561-4.

34. Seiler R, Ashab HAD, Erho N, van Rhijn BWG, Winters B, Douglas J, Van Kessel KE, Fransen van de Putte EE, Sommerlad M, Wang NQ, Choeurng V, Gibb EA, PalmerAronsten B, Lam LL, Buerki C, Davicioni E, Sjödahl G, Kardos J, Hoadley KA, Lerner SP, McConkey DJ, Choi W, Kim WY, Kiss B, Thalmann GN, Todenhöfer T, Crabb SJ, North S, Zwarthoff EC, Boormans JL, Wright J, Dall'Era M, van der Heijden MS, Black PC. Impact of molecular subtypes in muscle-invasive bladder cancer on predicting response and survival after neoadjuvant chemotherapy. Eur Urol. 2017;72(4):544-54. https://doi.org/10.1016/j.eururo.2017. 03.030 .

35. Robertson AG, Kim J, Al-Ahmadie H, Bellmunt J, Guo G, Cherniack AD, Hinoue T, Laird PW, Hoadley KA, Akbani R, Castro MAA, Gibb EA, Kanchi RS, Gordenin DA, Shukla SA, Sanchez-Vega F, Hansel DE, Czerniak BA, Reuter VE, Su X, de Sa Carvalho B, Chagas VS, Mungall KL, Sadeghi S, Pedamallu CS, Lu Y, Klimczak LJ, Zhang J, Choo C, Ojesina AI, Bullman S, Leraas KM, Lichtenberg TM, Wu CJ, Schultz N, Getz G, Meyerson M, Mills GB, McConkey DJ, Research Network TCGA, Weinstein JN, Kwiatkowski DJ, Lerner SP. Comprehensive molecular characterization of muscle-invasive bladder. Cancer Cell. 2017;171(3):540-556.e2. https://doi.org/10.1016/j.cell.2017.09.007.

36. McConkey DJ, Choi W, Ochoa A, Siefker-Radtke A, Czerniak B, Dinney CP. Therapeutic opportunities in the intrinsic subtypes of muscle-invasive bladder cancer. Hematol Oncol Clin North Am. 2015;29(2):377-94, x-xi. https:// doi. org/10.1016/j.hoc.2014.11.003.

37. Joerger M, Cassier PA, Penel N, et al. Rogaratinib in patients with advanced urothelial carcinomas prescreened for tumor FGFR mRNA expression and effects of mutations in the FGFR signaling pathway. JClin Oncol. 2018;36(suppl):abstr 4513.

38. Siefker-Radtke AO, Necchi A, Park SH, et al. First results from the primary analysis population of the phase 2 study of erdafitinib (ERDA; JNJ-42756493) in patients (pts) with metastatic or unresectable urothelial carcinoma (mUC) and FGFR alterations (FGFRalt). J Clin Oncol. 2018;36(suppl):abstr 4503.

39. Fradet Y, Bellmunt J, De Wit R, et al. Pembrolizumab (pembro) versus investigator's choice (paclitaxel, docetaxel, or vinflunine) in recurrent, advanced urothelial cancer (UC): 2-year follow-up from the phase 3 KEYNOTE-045 trial. JClin Oncol. 2018;36(suppl):abstr 4521.

40. Powles T, Durán I, van der Heijden MS, Loriot Y, Vogelzang NJ, DeGiorgi U, OudardS, Retz MM, Castellano D, Bamias A, Fléchon A, Gravis G, Hussain S, Takano T, Leng N, Kadel EE 3rd, Banchereau R, Hegde PS, Mariathasan S, Cui N, Shen X, Derleth CL, Green MC, Ravaud A. Atezolizumab versus chemotherapy in patients with platinum-treated locally advanced or metastatic urothelial carcinoma (IMvigor211): a multicentre, open-label, phase 3 randomised controlled trial. Lancet. 2018;391(10122):748-57. https://doi.org/10. 1016/S0140-6736(17)33297-X.

41. Challita-Eid PM, Satpayev D, Yang P, An Z, Morrison K, Shostak Y, Raitano A, Nadell R, Liu W, Lortie DR, Capo L, Verlinsky A, Leavitt M, Malik F, Aviña H, Guevara CI, Dinh N, Karki S, Anand BS, Pereira DS, Joseph IB, Doñate F, Morrison K, Stover DR. Enfortumab vedotin antibody-drug conjugate targeting nectin- 4 is a highly potent therapeutic agent in multiple preclinical cancer models. Cancer Res. 2016;76(10):3003-13. https://doi.org/10.1158/0008-5472. CAN-15-1313.

42. Rosenberg JE, Sridhar SS, Zhang J, et al. Updated results from the enfortumab vedotin phase 1 (EV-101) study in patients with metastatic urothelial cancer (mUC). J Clin Oncol. 2018;36(suppl):abstr 4504.

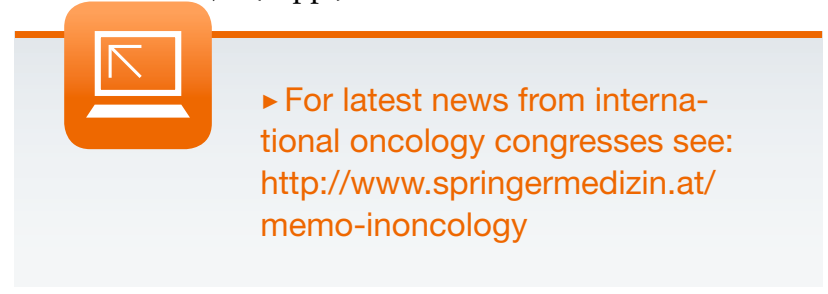

